\title{
Group Guidance Based on Gestalt Theory to Develop Creativity in Learning
}

\section{Rizki Diana Putri}

Universitas Negeri Semarang

Rizkidianaputri84@gmail.com

\author{
Submitted: 2019-11-03, Revised: 2019-11-15, Accepted: 2019-12-01
}

\begin{abstract}
Creativity in learning is a character that is the power of individuals to be able to complete their competence in learning. In learning, creativity makes students sensitive or aware of problems, shortages, understanding in knowledge, by gathering existing information, limiting information, or connecting (looking for) nothing, finding answers, making hypotheses, changing, and testing them. It is accepted and finally communicates the results. The purpose of this study is to get a complete picture of the learning process and group guidance using Gestalt in developing learning creativity. The research method uses literature studies. In operational terms, creativity in learning requires students to be able to reflect the abilities that are responsible for the burden, burden, and the learning process. The understanding resulting from the reflection process becomes a reference in the formulation of the problem. The results of the literature study show that group guidance with Gestalt theory can help students develop their creativity in learning. Give advice about assistance when interacting and interpersonal problems, as well as creativity assistance, implemented to support/bring up productive solutions in efforts to improve Gestalt. Gestalt-based group tutoring to develop learning creativity gathers students to find opinions about the challenges of learning, to finally find the discovery of actions that are appropriate for yourself. Group techniques that can be used are lap exercises, fantasy exercises, and homework.
\end{abstract}

Keywords: Creativity; Gestalt; Group Guidance

\section{Introduction}

Creativity is one of the supporting fields in learning Creativity has become a part of $4 \mathrm{C}$, namely 21 st-century student competencies. The results of Jules \& Sundberg's research (2018) which showcases international research, creativity that is in accordance with the five competitions needed by students. In this research also needs to learn in the school that is needed and creativity in every field of studio study, or in school activities.

Students who have creativity support strengths in everyday life. Creativity makes humans to give, content, style, and nuances in their lives (Supriadi, 2001). In line with this, Nurfaizal (2016) in his research found that creative individuals will have courage, selfefficacy (beliefs), hopes (hopes), and optimism to make changes in every conversation they face. Therefore, students will not easily get bored and bored.

Learning is essentially a holistic adaptation process (complete). Learning is not only the result of awareness, but involves the integrative process of various functions of the self, such as thinking, pleasing, understood, and behaving. Success in the learning process involves various functions in every aspect needed by individuals, both physical and psychological. Creativity in learning is needed to optimize the function of various aspects of the individual self.

Nasution (2016) states creativity as a collected mental process, process, new production method that is effective imaginative, aesthetic, flexible, integration, succession, discontinuation, and efficient variation in various fields for problem-solving. Based on this opinion, group guidance can be an alternative to developing creativity. The results of Jawandi, Sugiharto, \& Tadjri (2016) research show that in the implementation of group counseling, students will be asked questions that can help smooth discussion, improvisation will train the ability to think flexibly and accordingly, which is related to new things will be fostered by considerations or desires that want to displayed from personal experience. 
Guidance groups that discuss individual assistance, or also called holistic (Kolb \& Kolb, 2009). The Gestalt Model is an adaptation model, which starts from scientific activities towards problem-solving, decision making, and creativity. Group approval can be adapted into psychoeducational guidance arrangements.

Therefore, an article entitled Gestalt-based group guidance was arranged for the development of student creativity in learning. Development of creativity in learning through groups consisting of psychoeducational processes that integrate all individual functions in the creative

\section{Methods}

The study was conducted using the literature study method. Sources of research data obtained through research on scientific articles in journals, textbooks, and survey results that focus on developing creativity and applying Gestalt theory.

\section{Results and Discussion}

Creativity as an Individual Psychological Power

Creativity is obtained from the word create which is to make, produce, or make. Fakhriyani (2016) suggests creativity as the ability to make new combinations, based on data, information, or elements that already exist or are previously known, namely all the experience and knowledge one has gained about how to improve it in the school, family, or environment. the community. Marliani (2015) Thus, creativity is also referred to as the ability to improve and develop understanding to solve problems.

Creativity is often associated with words such as new, unusual, ideas, extraordinary, challenging, unique, interesting, strange, open, running away, or something very different. The terms of the term refer to individual strengths, both within and outside the Environment. In everyday life, creative people are people who can show the difference, because people who think differently from other people.

Guilford advocates creativity is a way of thinking divergent ways of converging (Irawan, 2018). Divergent creative thinking, creative thinking heuristic, and lateral thinking. Creativity is the tendency to come up with new and original creative ideas and behavior. Interesting ideas and behaviors are not only different, the most important of which are able to inspire and provide benefits for life. This makes creativity an individual's strength. Creative ideas produced by individuals are basically problem-solving, with the process of being understood and interpreted in the world (environment).

Creativity is not only the ability to determine self-critical, but also the ability to make something new in this case, the relationship with the environment, both in terms of material, social and psychological. In line with the opinion of Woolfook (Mardhiyana \& Sejati, 2016) which explains creativity as the ability of individuals to produce something (result) that is new or original or solving a problem.

Creativity becomes urgent for individuals because it is not only the process of generating new ideas, it requires an adaptation process. Peterson \& Seligman (2004) explained adaptive as an important component in creativity, in addition to originality. To be adaptive the originality of an individual must make a positive contribution to the life carried out or the lives of others. Creative living means learning to use one's own abilities optimally, developing their talents, finding motivation and learning new activities, and developing sensitivity to environmental problems and welfare issues (Munandar, 2009).

Individuals who have creativity are expected to have the power to make constructive changes to improve and improve their lives. Creativity encourages individuals to think about things in new and unusual ways and produce unique solutions to problems, and discover or create new things, new ways, new models that are useful to help and for the community. 


\section{Creativity in Learning}

Tornace and Myres assess that the characteristics of creativity in learning are: sensitive or aware of problems, shortcomings, insights in knowledge, nothing that does not exist, disharmony and so on (Setyaningrum, 2015). Gathering existing information, limiting difficulties, or showing (connecting) nothing that does not exist, looking for answers, making hypotheses, changing and testing it, completing and finally communicating the results ".

Creativity in learning requires students to be able to reflect the abilities supported by the burden, and the learning process. The understanding resulting from the reflection process becomes a reference in the formulation of the problem.

Creative process of learning. Want incompetence, incompleteness, involving, difficulty, disharmony, irregularity in a learning process. The simplicity of structure or diagnosing a problem by synthesizing information that is already owned, making combinations and diverging by creating new alternatives, discussing new updates, and so on. Considering, agreeing, deciding, and discussing recently, putting aside, solving what is not successful, wrong and not good, choosing the most interesting and pleasing solution, aesthetically, conforming the results to others (Semiawan, 2009).

Thus in creative learning, it must involve the components of the most pleasant and most unpleasant learning experiences and then discovering facts in the creative learning process is very possible among the experiences of learning that are very pleasant, experiences that are very useful for us and are very useful for us. So learning creativity can be interpreted as the ability of students to create new things in learning both consisting of the ability to develop the abilities obtained from the teacher in the teaching and learning process that contains knowledge that can make new combinations in learning

\section{Application of Gestalt Theory to Group Guidance}

The application of gestalt theory to group counseling activities is a psychoeducational activity in organizing groups based on Gestalt agreement. Group guidance activities take into consideration the principles and therapeutic relationships of the Gestalt theory.

In basic gestational theories, the process of developing perception is the most important point. The characteristic of gestalt psychology developed by Koffka is seeing how someone perceives someone will determine everyone in making certain ideas and solutions. Perception is the process of someone who is received, approved, and given information that comes from their sensory organs. The results of Necka's research show Perception influences every action related to the way people find out how to find out what happened. If their perceptions are different from others, their thoughts will lead to creative ideas (Nęcka, 2017).

Gleadding \& Samuel (2012) suggests four basic principles in the application of Gestalt theory, namely:

1. Overall principle (integration), individuals will do unfinished work about transition and implementation. Individuals are depleted of incompleteness, division in order to be received whole again,

2. Awareness Principle: people are free to choose only if they are self-aware. The concept of awareness of all the difficulties, thoughts, behavior experienced,

3. The principle of figure/background, consists of very important experiences, for example, the decisions of people who really hate him, while the background consists of unpleasant experiences that occur when he is.

4. The principle of polarity, if the counselee addresses his needs, they must first determine their perceptual experience in the opposite form, for example, active/passive, good/bad. This counselee's thinking is to explain the side of 
polarity or conflict and subsequently integrate this experience holistically. The counselee's failure to deal with internal conflict with others is caused by being unrelated to the opposite side of the effect.

The calculation process based on the assumptions of groups is a multidimensional system, which works at several levels at once. Group with individuals who form a unity that is interrelated and has a function, so it is called holistic. It is impossible to discuss counselee in groups outside of group interaction.

The counselor represents the center of the Gestalt group, which is the person who determines what will happen, with whom, and when certain interactions will occur. One of the counselors' work in this Gestalt group is the counselee's help localizing suggestions and ways of working through them will increase awareness and growth will be obtained (Corey, 2011). The counselor's role is as a balance between support and challenge.

Zinker sees the role of the counselor in this process as an artist. The role needed by the counselor to create an atmosphere that promotes growth in the group and the creativity of the group itself. Separately the counselor can be divided into roles as (a) expert-helper, (b) communication expert, (c) frustrated, (d) creator, and (e) teacher who can be used when needed to students (Ashbolt, 2018).

The desired outcome of the Gestalt group process is that students will be more aware of themselves here and now so that they can overcome the problem of neurosis. Students can minimize, and become more capable. In addition, they support the use of other ways to support, not someone who is very cognitive. This is evidenced by the Mayangsari research which uses gestational theory with paradoxical techniques to increase student confidence, increasing students increasing challenges to get acceleration that makes the comfort zone, so that it can be used outside the box (another term for creative) (Mayangsari, 2019).

\section{Creativity at Gestalt Group Meetings and Techniques}

Gestalt theory enjoys the development of awareness as well as the creative process which are important processes for human health. Amendt - Lylon (Lisa Hirsh \& CAS, 2014) supports the compilation of someone working through conflict and interpersonal problems, as well as supporting creativity that can be implemented to support/bring up productive solutions in supporting Gestalt therapy. In the Gestalt concept, the process of forming creativity is determined by the ability of individual eyes to pay attention to the holistic environment (Rumli, 2018).

Gestalt based guidance activities can be a creative process. Zinker (Ashbolt, 2018) summarizes the position with the basic principles of Gestalt therapy as "a way to be creative", and he shows that counselors can experiment, be creative, and with regard to design to determine areas that are difficult to question. The process of therapy and creativity at the time of Gestalt is related to the level of transformation, metamorphosis, and change.

The aim of the Gestalt technique is to concretize and symbolize one's inner life, expressing aspects with wide variations through the media (Ashbolt, 2018). The therapeutic process is like making art. The creative process in the Gestalt engineering group is to treat people before them comprehensively, providing an environment, atmosphere (atmosphere) so that one's integrity can be better understood.

To bring out creativity through Gestalt-based guidance, a counselor must be able to create creative stimulation. The counselee's creativity will be formed from how to respond to the stimuli provided by the counselor so that mutual relations emerge that are mutually aware and well-integrated as a creative perceptual process.

Variety of Techniques in Gestalt Group Guidance 
Group counseling with Gestalt focuses on experiences here and now. "What" and "how", not "Why". Group guidance is an attempt to resolve the counselee on the agreed-upon situation and the skills needed to solve the problem.

The counselor asked Gestalt to ask his advisers to work with specific problems to help raise greater awareness. Conversations between counselor and counselee with other group members serve as background. The focus that has been ignored is the focus and responsibility of the individual. Third, the emphasis is on the cognitive transition process (Zinker, 2009).

Gestalt group guidance uses experiments and exercises, which are developmentoriented and therapeutic. These experiments and exercises develop five main themes, namely: (a) the enactment (acting clearly), (b) direct practice, (c) fantasy, (d) dreams, and (e) homework (Polster \& Polster, 2013).

\section{Implementation of Gestalt Group Guidance to Develop Creativity in Learning}

Creativity in learning that is challenging for those who know, and who overcomes difficulties in learning, and enhances those for achievement, through appropriate means.

The survey conducted by Ofsted (Office for Standards in Education, Child Services and Skills) in 2010, revealed the actions of educators who encouraged increased student creativity in learning among the following.

1. Encourage students to accept safely bringing up their opinions and ideas about the learning process,

2. Facilitating to bring up ideas/designs that are different from the effective learning process

3. Making connections between aspects, problems, and learning abilities, so as to be able to experiment with complex problem-solving.

4. Review their constructive learning with their peers, so that they accept each other's ideas.

The key to generating creativity in learning is the freedom to find and explore ideas about compelling learning. Students are guided to find out about learning or learning problems until they are able to find a plan that feels appropriate for him.

The results of the study that discusses three techniques that can be done in the implementation of gestalt group guidance to develop student learning creativity.

1. The engineering round is a technique at Gestalt to openly discuss and discuss each other's problems. In this exercise, students can say to all group members, "When studying ... I can / think because ....... when I try to ...... what happens is ... "this example makes students become aware of the conversation being carried out by each group member, in learning. In addition, students are entitled to the opportunity to be invited.

2. Fantasy exercises help students become more aware of their feelings, hopes, doubts and difficulties. Fantasy is one of the techniques and processes in the Gestalt group. Students choose to think about when learning, then they express their views of the fantasy they do.

3. Completing homework is a form of framing. Students practice ideas they should try in groups, for example asking for help trying communication with the teacher.

The group guidance process to find out how to stimulate students to find diverse ideas from experiences exploring various feelings and understanding will help learning. The ideas obtained are tested, so it becomes creativity in solving various difficulties in learning. 
Strength and Limitations Analysis of the Gestalt Technique

There are several advantages that can be stated from this Gestalt group, namely: this group focuses group work on the target and is more integrative. Specifically, this group is appropriate for counselors who choose to ask for a humanistic existential in helping others. This advice makes the counselee will help each other so that it is more useful and not lonely. To help the groups involved, there are many training institutes that can be used by professionals who want to ask for this assistance, so that through various exercises and experiments the groups increase continuously and actively.

In addition to the benefits above, there are also restrictions that can be stated as follows.

a. Assessing Gestalt has a desire to avoid the cognitive side of human nature. Counselors sometimes set dead ends and are unable to make counsel.

b. Technique and attention to approvals is currently lacking. This condition is suggested by the lack of or found relevant research with this Gestalt group.

\section{Conclusions and Suggestions}

Creativity encourages individuals to think about things in new and unusual ways and produce unique solutions to problems, and discover or create new things, new ways, new models that are useful to help and for the community. Creativity in learning helps students to find solutions to problems and study learning that they face. The calculation process based on the assumptions of groups is a multidimensional system, which works at several levels at once. Group with individuals who form a unity that is interrelated and has a function, so it is called holistic. Group guidance process. Demands for students. For this group, participants can learn about how to get help. Group techniques that can be used are lap exercises, fantasy exercises, and homework.

To apply guidance based on Gestalt theory BK teachers must provide the following experience (1) Encouraging students to get safe raising their opinions and ideas about the learning process, (2) Facilitating to come up with ideas / planning that are appropriate to the needs of effective learning processes (3) Making connections between aspects, problems and learning abilities, so as to be able to experiment with practical problem solving. (4) Reviewing their constructive learning with their peers, so that they accept each other's ideas.

\section{References}

Ashbolt, K. (2018). Re-evaluating creativity and play: A literature review. Gestalt Journal of Australia and New Zealand, 15(1), 54.

Corey, G. (2011). Theory and practice of group counseling. Nelson Education.

Fakhriyani, D. V. (2016). Pengembangan kreativitas anak usia dini. Wacana Didaktika, 4(2), 193-200.

Gleadding \& Samuel, T. (2012). Konseling Profesi Yag Menyeluruh. Jakarta: PT. Indeks.

IRAWAN, H. (2018). Hubungan Antara Kreativitas Dengan Kebijaksanaan Pada Mahasiswa (Studi Pada Mahasiswa Fakultas Psikologi UIN Sultan Syarif Kasim Riau). Universitas Islam Negeri Sultan Syarif Kasim Riau.

Jawandi, A., Sugiharto, D. Y. P., \& Tadjri, I. (2016). Efektivitas Bimbingan Kelompok Teknik Gamestorming dan Teknik Token Economy untuk Meningkatkan Kreativitas Siswa SMP Islam Diponegoro Surakarta. Jurnal Bimbingan Konseling, 5(2), 78-85.

Kolb, A. Y., \& Kolb, D. A. (2009). Experiential learning theory: A dynamic, holistic approach to management learning, education and development. The SAGE Handbook of 
Management Learning, Education and Development, 42-68.

Lisa Hirsh, M. E. D., \& CAS, G. C. C. (2014). Sparking Creative Confidence and Action: A Coach's (Gestalt) Journey. Gestalt Review, 18(2), 172-182.

Mardhiyana, D., \& Sejati, E. O. W. (2016). Mengembangkan Kemampuan Berpikir Kreatif dan Rasa Ingin Tahu Melalui Model Pembelajaran Berbasis Masalah. PRISMA, Prosiding Seminar Nasional Matematika, 672-688.

Marliani, N. (2015). Peningkatan Kemampuan Berpikir Kreatif Matematis Siswa melalui Model Pembelajaran Missouri Mathematics Project (MMP). Formatif: Jurnal Ilmiah Pendidikan MIPA, 5(1), 14-25. https://doi.org/10.30998/formatif.v5i1.166

Mayangsari, E. (2019). Efektivitas Pendekatan Gestalt Dengan Teknik Paradoxical Intervention Untuk Meningkatkan Rasa Percaya Diri Siswa. JIMBK: Jurnal Ilmiah Mahasiswa Bimbingan \& Konseling, 4(2).

Munandar, U. (2009). Kreatifitas Pengembangan Anak Berbakat. Jakarta: Rineka Cipta.

Nasution, S. W. R. (2016). Pengaruh Model Pembelajaran Inquiri Terbimbing Dan Kreativitas Terhadap Hasil Belajar Kognitif Tinggi Fisika Siswa. UNIMED.

Nęcka, E. (2017). Perception and Creativity the Rerence Module in Neuroscience and Biobehavioral Psychology, 1-5. https://doi.org/10.1016/b978-0-12-809324-5.06252-0

Nurfaizal, Y. (2016). Modal psikologis kreatif creative psychological capital (CrePsyCap). Probisnis, 9(2).

Peterson, C., \& Seligman, M. E. P. (2004). Character strengths and virtues: A handbook and classification (Vol. 1). Oxford University Press.

Polster, E., \& Polster, M. (2013). From the radical center: The heart of Gestalt therapy. Gestalt Press.

Rumli, R. (2018). Pembentukan Karakter Kreatif Peserta Didik. I’TIBAR, 6(11), 119-132.

Semiawan, C. R. (2009). Memupuk Bakat dan Kreativitas Siswa Sekolah Menegah. Jakarta: PT Gramedia.

Setyaningrum, E. (2015). Pengaruh Layanan Penguasaan Konten Terhadap Kreativitas Belajar Siswa Kelas VIII SMP Negeri 2 Karangrayung Purwodadi Tahun Ajaran 2015/2016. Universitas Negeri Semarang.

Supriadi, D. (2001). Kreativitas, kebudayaan, dan perkembangan iptek. Alfabeta.

Zinker, J. C. (2009). Gestalt therapy is permission to be creative: A sermon in praise of the use of experiment in Gestalt therapy. Gestalt Review, 13(2), 123. 
